Pobrane z czasopisma Annales I - Philosophy and Sociology http://philosophia.annales.umcs.pl Data: 26/04/2023 10:14:19

10.1515/sectio-2015-0031

A N N A L ES

UNIVERSITATIS MARIAE CURIE-SKŁODOWSKA

LUBLIN - POLONIA

VOL. XL, 2

SECTIO I

2015

ŁUKASZ STEFANIAK

Uniwersytet Marii Curie-Skłodowskiej

\title{
Dwubiegunowa typologia społeczeństw Murraya Rothbarda
}

Bipolar Typology of Societies by Murray Rothbard

W literaturze można znaleźć rozmaite typologie społeczeństw. Wszystkie opierają się na pewnych ustalonych kryteriach. Niejednokrotnie zasadzone są w kontekście historycznym i przyjmują formę faz ewolucji, przez które musi przejść zbiorowość ludzka zamieszkująca dane terytorium. Współcześnie najbardziej charakterystyczna dla socjologii pozostaje klasyfikacja wyróżniająca społeczeństwa pierwotne, rolniczo-chłopskie, industrialne i postindustrialne ${ }^{1}$. W skład tych pozycji mogą wchodzić różne podtypy mające określać bardziej precyzyjnie charakterystykę danej struktury. Ich wielość i wzajemne nakładanie się na siebie nie sprzyjają jednak klarowności dyskursu. Rozwiązaniem tego problemu może być znacznie prostszy podział, opierający się na dwóch typach idealnych, których elementy można odszukać nie tylko w każdym istniejącym w przeszłości społeczeństwie, ale także w każdym społeczeństwie współczesnym.

Typologia, którą zaproponował amerykański intelektualista Murray Rothbard opiera się na prakseologicznym ${ }^{2}$ ujęciu pojęcia wolności. Wyróżnił on dwa typy społeczeństw: hegemoniczne i kontraktowe ${ }^{3}$. Wyróżnikiem każdego z nich są relacje. Każdy typ interakcji, zachodzący pomiędzy konfiguracją dowolnej liczby ludzi, ma swoje źródło w działaniach, które ci ludzie podejmują. Ukonstytuowanie danego typu społeczeństwa zależy zatem od dominującego typu działań mających miejsce na określonym obszarze. Powyższym typom społeczeństw odpowiada charakterystyczny dla nich typ interakcji międzyludzkich. Są to działania inwa-

\footnotetext{
1 J. Turowski, Socjologia. Wielkie struktury społeczne, Lublin 2000, s. 88.

2 Najprościej jest zdefiniować prakseologię jako „ogólną teorię ludzkiego działania”. Zob. L. von Mises, Ludzkie działanie. Traktat o ekonomii, Warszawa 2011, s. 3.

3 M.N. Rothbard, Ekonomia wolnego rynku, t. 1, Warszawa 2007, s. 214.
} 
zyjne dla społeczeństwa hegemonicznego i działania nieinwazyjne dla społeczeństwa kontraktowego. Najczęstszym przypadkiem są społeczeństwa wykazujące oba typy interakcji, dlatego podział taki trzeba traktować raczej jako dwubiegunową typologię osiową, a nie kategoryzację na dwie oddzielne i zamknięte grupy.

Obie kategorie mają pewną charakterystyczną dla siebie cechę. W przypadku społeczeństwa hegemonicznego jest to przymus. Relacje, które powstają w społeczeństwie hegemonicznym, odznaczają się jakąś formą niedobrowolnych działań, określanych mianem przemocy. Niezbędne zatem jest zdefiniowanie, czym tak naprawdę ona jest i jaką formę może przyjmować.

W tradycji intelektualnej, do której należał sam Rothbard, podjęto kilka prób sprecyzowania, czym jest przemoc. Najbardziej znanej dokonał noblista Friedrich August von Hayek. Definiował on przemoc w bardziej ogólnych kategoriach samego przymusu, opisywanego jako sytuacja występująca, ,gdy działania jednego człowieka są podporządkowane woli innego człowieka, jego celom, a nie własnym celom tego pierwszego"4. Istnienie takiego dyktatu nie zakłada naturalnie, że podmiot mu poddawany nie posiada żadnych alternatyw w swoim działaniu. Należy na to patrzeć w ten sposób, że sprzeciwienie się woli agresora będzie bardziej dotkliwe w skutkach, w ocenie podmiotu podlegającego przymusowi, niż podporządkowanie się jego arbitralnym rozkazom. Według Hayeka nie każda forma wpływu jednego człowieka na drugiego zalicza się do takiego przypadku. Przykładowo wyklucza on, że sytuację, w której ktoś przepędza inną osobę swoim głośnym zachowaniem z jakiegoś pomieszczenia, należy uznać za działanie mające charakter przymusu. Choć postępowanie takie może (ale nie musi) mieć na celu skłonienie danej osoby do określonego zachowania, to do zaistnienia rzeczywistego przymusu konieczne byłoby jeszcze zagrożenie wyrządzenia konkretnej szkody5.

Hayek do swojej kategorii działań opartych na przymusie i przemocy zaliczył także działania, co do których można mieć wątpliwości, czy spełniają wystarczające przesłanki pozwalające je $\mathrm{w}$ ten sposób zaszeregować. Pośrednio włączył do niej na przykład zrzędliwe zachowanie małżonka, które może uczynić nieznośnym życie partnera. Co prawda, autor sam zaznacza, że nie opowiada się za karaniem takich przypadków, jednakże - jak można wykazać - w gruncie rzeczy akceptuje pomysł zaklasyfikowania ich pod tę kategorię ${ }^{6}$. Traktowanie przepełnionego goryczą zachowania jako działania inwazyjnego jest dużym nieporozumieniem choćby z uwagi na fakt, że osoby pozostające razem w związku robią to dobrowolnie, tzn. nie ma żadnych przeszkód fizycznych, żeby mogli się rozstać ${ }^{7}$.

4 F.A. von Hayek, Konstytucja wolności, Warszawa 2011, s. 141.

Ibidem, s. 141-142.

6 Zob. M.N. Rothbard, Etyka wolności, Warszawa 2010, s. 338-339.

7 Potencjalny niedostatek materialny nie zmienia tej sytuacji. Nawet $\mathrm{w}$ takim przypadku oboje małżonkowie posiadają pełną wolę decyzyjną odnośnie własnej osoby, w tym do poprawienia swojej sytuacji materialnej. 
Błędne jest również sugerowanie, że odmowa wykonania jakiejś czynności w pewnych określonych okolicznościach może być oceniana jako przymus. W sytuacji gdy na jakimś terenie wybucha epidemia i jest tylko jeden lekarz, który może prowadzić skuteczną terapię, jego hipotetyczna ucieczka nie może zostać uznana za działanie inwazyjne. Jest to naturalnie negatywne, a nawet niedopuszczalne z moralnego punktu widzenia i szkodliwe z praktycznej strony dla społeczności dotkniętej takim nieszczęściem. Nie można jednak każdego rodzaju działania szkodliwego klasyfikować automatycznie jako niosącego ze sobą cechy przymusu. Jeśli zaś zaliczyć do tej kategorii tylko niektóre z nich, to kryteria będą miały charakter czysto subiektywny, a nie poparty adekwatnymi argumentami natury niewartościującej8.

Koncepcja przymusu Hayeka zawiera zatem pewne luki wywołujące poważne problemy. Bardziej spójną perspektywę teoretyczną działań inwazyjnych opracował sam Rothbard. Według tej koncepcji mogą one przyjmować charakter bezpośredniej przemocy, kiedy ktoś, stosując ją, nakłania innych do określonych zachowań. Przemoc ta nie musi być bezpośrednia, przymus można bowiem wyegzekwować także przy użyciu samej groźby jej użycia. Pod względem rezultatu takich działań, nie ma pomiędzy nimi żadnej różnicy. Zarówno otwarta przemoc, jak i zastraszenie są elementami charakterystycznymi dla działań hegemonicznych, czyli również dla odpowiadających im społeczeństw ${ }^{9}$. Konieczne jest wobec tego zaklasyfikowanie do nich też wszelkich interakcji opierających się na niewolnictwie. W takim przypadku bowiem może nie dochodzić do bezpośredniej przemocy pana względem poddanego, ale ten drugi musi wykonywać polecenia, mając świadomość, że grozi mu tego rodzaju przemoc ${ }^{10}$.

Agresja wiąże się ze stratą, jaką ponosi obiekt będący jej przedmiotem. Skierowana jest zatem przeciwko należącej do niej własności. Rozumieć przez to trzeba zarówno przemoc wobec danej osoby (czyli wobec ciała do niej należącego), jak i dóbr, w których posiadanie weszła za pomocą pokojowych metod. Strata, którą ponosi ofiara, może przyjąć postać materialną (kradzież) lub moralną, określaną mianem straty stricte psychicznej. Odpowiednio silne natężenie działań inwazyjnych $\mathrm{w}$ danej społeczności prowadzi do wykształcenia społeczeństwa hegemonicznego.

Jak argumentuje Rothbard, osoba stosująca działania inwazyjne wobec innych w celu uzyskania korzyści, pełni społeczną funkcję drapieżnika lub pasożyta. Korzysta z owoców pracy innych. Można powiedzieć, że marnotrawi ich

8 Z kwestią tą wiąże się problem słuszności utylitaryzmu. W ramach tego krótkiego tekstu nie jest możliwe jego satysfakcjonujące opracowanie. Szczegółowe omówienie tej kwestii można znaleźć np. w: R. Nozick, Anarchia, państwo i utopia, Warszawa 2010, s. 45-61.

9 M.N. Rothbard, Ekonomia wolnego rynku, s. 201-202.

10 Ibidem, s. 203-205. 
energię, a w najlepszym przypadku nie dodaje niczego użytecznego do dorobku społeczeństwa. W praktyce działania hegemoniczne prowadzą do obniżenia jakości i ilości dóbr wytwarzanych przez pozostałe osoby. Zakładając, że tego typu relacje dominowałyby przez wystarczająco długi czas, doszłoby do zaniku produkcji i śmierci zarówno ofiar, jak i samych pasożytów. Niekorzystne skutki takich interakcji obejmują zatem nie tylko osoby bezpośrednio nimi dotknięte, ale całe społeczeństwo ${ }^{11}$. Należy poddać w wątpliwość, czy funkcjonowanie społeczeństwa hegemonicznego ma jakikolwiek potencjał rozwojowy, przynajmniej w perspektywie długoterminowej.

W przypadku społeczeństwa kontraktowego wzajemne relacje pomiędzy ludźmi opierają się nie na przymusie i przemocy, tylko na dobrowolnej współpracy. Przyjmuje ona formę oficjalnych lub nieoficjalnych kontraktów, które zawierają pomiędzy sobą zainteresowane podmioty. Społeczeństwo takie składa się z sieci nienarzuconych przez nikogo interakcji, określanych przez autora terminem ,wymian”. Zastosowanie w tym przypadku pojęcia kojarzonego przede wszystkim z ekonomią ma swoje uzasadnienie. Celem każdego działania, którego podejmuje się człowiek, jest ogólnie pojęta poprawa sytuacji, w jakiej się znajduje, choćby ta poprawa miała wymiar jedynie psychiczny. Działanie polega zatem na zamianie gorszej sytuacji na sytuację, w ocenie tej konkretnej osoby, lepszą. Taki jest też główny motyw osób decydujących się przystąpić do interakcji społecznej.

W pełni kontraktowe społeczeństwo w ocenie amerykańskiego autora opiera się na tzw. aksjomacie o nieagresji, którego fundamentem jest prawo do własności prywatnej. Oznacza to, że nikt nie ma prawa dokonywać agresji na daną osobę lub należącą do niej własność, jeśli sama nie zainicjowała przemocy jako pierwsza. Jedynym uprawnionym użyciem przemocy w społeczeństwie kontraktowym jest samoobrona ${ }^{12}$. Korzenie tej idei sięgają dużo dalej w przeszłość niż twórczość samego Rothbarda. Łatwo zauważyć, że nieodłącznie wiąże się ona z prawami jednostek, które formalny wymiar nabrały wraz z publikacją Dwóch traktatów o rzadzie Johna Locke'a ${ }^{13}$. Aksjomat o nieagresji, po raz pierwszy w krystalicznej i zbliżonej do Rothbarda formie, ujął żyjący na przełomie XIX i XX wieku amerykański filozof prawa Zechariah Chafee. Jego słowa o tym, że „twoje prawo do wymachiwania ręką kończy się tam, gdzie zaczyna się nos drugiego człowieka"14 ${ }^{14}$ przypisywane często niesłusznie Oliverowi Wendellowi Holmesowi Juniorowi, są niczym innym niż podstawą społeczeństwa kontraktowego. Warto dodać, że do podobnej idei na-

11 Idem, Etyka wolności, s. 133-134.

12 Idem, War, Peace, and the State, [w:] Egalitarianism as a Revolt Against Nature and Other Essays, Auburn 2000, s. 116.

${ }_{13}$ Zob. J. Locke, Esej dotyczacy prawdziwych początków, zakresu i celu rządu obywatelskiego, [w:] Dwa traktaty o rządzie, Warszawa 1992, s. 178-179, 181-182.

14 Z. Chafee, Freedom of Speech in War Time, "Harvard Law Review" 1919, No. 32, s. 957. 
wiązywał wcześniej John Stuart Mill ze swoją „zasadą krzywdy”"15, jednakże jego utylitarne podejście do kwestii społecznych jest dalekie od poglądów Rothbarda.

Dobrowolność działań kontraktowych należy zawsze zestawiać z zachowaniami hegemonicznymi, opartymi na przemocy. Tylko w ten sposób można uniknąc intelektualnych nieporozumień wokół aksjomatu o nieagresji. W celu bardziej precyzyjnego określenia idei opartego na nim społeczeństwa trzeba także odwołać się do tego, jak funkcjonuje przykładowy kontrakt zawierany dobrowolnie przez obie strony interakcji. Cały proces wymiany zasadza się bowiem na posiadanych przez poszczególne podmioty tytułach własności, a konkretnie na mocy zrzeczenia się ich przez jedną osobę na rzecz drugiej przy zachowaniu warunków, na które obie strony zgodziły się i je świadomie akceptują. Istotne jest, że w społeczeństwie kontraktowym nie mogą obowiązywać umowy mające na celu pozbawienie innej osoby wolnej woli. W przeciwnym wypadku oznaczałoby to istnienie sprzecznego logicznie konstruktu - „dobrowolnej niewoli”. Stan zniewolenia wyklucza dobrowolność, a dobrowolność zakłada, że człowiek może w każdej chwili odmówić posłuszeństwa swojemu zwierzchnikowi ${ }^{16}$. „Dobrowolna niewola" nie jest zatem albo dobrowolna, albo nie jest niewolą ${ }^{17}$.

Modelowym przykładem kontraktu, jaki mogą zawrzeć pomiędzy sobą dwie osoby jest, obok zwykłej wymiany handlowej, relacja występująca pomiędzy pracodawcą a pracownikiem. Jeżeli ktoś zawarł umowę z przedsiębiorcą, na mocy której wytworzy trzy jednostki określonego dobra, to w społeczeństwie w pełni kontraktowym może on się z niej wycofać bez żadnych konsekwencji, jeśli jeszcze nie doszło do wytworzenia żadnej jednostki tego dobra. Wynika to oczywiście z niezbywalności wolnej woli i tego, że w opisywanej chwili nie doszło jeszcze do przekazania jakichkolwiek praw własności. Egzekwowanie takiego kontraktu byłoby $\mathrm{w}$ istocie nieuprawnionym użyciem siły ${ }^{18}$. Nie zachodzą tutaj bowiem przesłanki umożliwiające podjęcie samoobrony. Pracownik mógłby też wycofać się po wytworzeniu jednej jednostki określonego w kontrakcie towaru. W takim przypadku pracodawca byłby zobowiązany zapłacić mu tylko za już wykonaną pracę (czyli za jedną jednostkę dobra).

Oczywiście z moralnego punktu widzenia powyższe zachowanie jest nieodpowiednie. Pracodawca ma jednak do dyspozycji instrumenty, które mogą skłonić aktora do wykonania pełnej pracy. Dobrowolność nie oznacza, że nikt nie ma prawa namawiać drugiej osoby do określonego zachowania. $Z$ pewnością przedsiębiorca poniósłby pewne straty w związku z niespodziewaną rezygnacją pracowni-

15 J.S. Mill, On Liberty, London 1921, s. 6.

16 Odmowa wykonania kontraktu, jak zostanie to pokazane w dalszej części, może się wiązać naturalnie z pewnymi konsekwencjami wynikającymi z jego postanowień. Kategoria „dobrowolności”, która jest tutaj podnoszona, zakłada po prostu brak przemocy i groźby jej użycia.

17 M.N. Rothbard, Etyka wolności, s. 123.

18 Idem, Ekonomia wolnego rynku, s. 315-317. 
ka, dlatego też mógłby wystosować do niego prośbę o dokończenie powierzonego mu zadania lub o wypłatę odszkodowania. Jeśli ten by się nie zgodził, wówczas pracodawca mógłby poinformować inne firmy o jego moralnej nieuczciwości, co z pewnością utrudniłoby mu dalszą karierę zawodową ${ }^{19}$. Ponadto gwarancję wykonania obowiązków dawałaby zapłata za wykonanie wszystkich jednostek towaru, jeszcze zanim pracownik przystąpiłby do realizacji zadania. W takim przypadku doszłoby do przekazania prawa własności (zapłaty), zatem powstałoby realne zobowiązanie, którego niewykonanie skutkowałoby prawem przedsiębiorcy do siłowego wyegzekwowania swoich należności na mocy prawa do samoobrony.

Całkowicie uprawnione w społeczeństwie kontraktowym, a nawet w wielu przypadkach wskazane, jest wykorzystanie bojkotu jako pokojowej formy nakłonienia jakiejś osoby lub instytucji do zmiany swojego postępowania. Naturalnie bojkot może być słuszny lub niesłuszny z punktu widzenia określonych kryteriów (na przykład moralnych), ale aksjomat o nieagresji zakłada dopuszczalność ich obu. W żadnym bowiem nie są wypełniane rothbardowskie przesłanki klasyfikujące dane zachowanie jako działalność inwazyjną. W sytuacjach wątpliwych jest możliwość zorganizowania kontrbojkotu, mającego przekonać zainteresowane osoby, że ten pierwotny jest całkowicie nieuzasadniony. Tak w społeczeństwie kontraktowym mogą być regulowane zachowania uznawane przez określoną grupę osób za niemoralne. Siła perswazji zastępuje w ten sposób argument siły ${ }^{20}$.

Innym przykładem działalności mającej na celu pokojowe przekonanie innych do swoich racji jest pikieta. Stwarza to jednak pewien zasadniczy problem na gruncie prawa własności. Jeżeli demonstranci blokują wejście do jakiegoś budynku prywatnego, to takie działania, na gruncie teorii społeczeństwa kontraktowego, należałoby potraktować jako agresywne. Podobnie byłoby w przypadku strajku okupacyjnego. Jeśli właściciel obiektu nie wyraziłby zgody na takie działania, to byłaby to przemoc skierowana przeciwko jego własności. O wiele bardziej skomplikowana sytuacja ma miejsce w przypadku publicznych ulic. Zachodzi tu bowiem nieuchronny konflikt pomiędzy tymi, którzy chcą wygłosić swoje racje a tymi, którzy pragną korzystać z dróg zgodnie z ich pierwotnym przeznaczeniem. Zakładając, że obie strony są płatnikami podatków, decyzja rządzących będzie zawsze arbitralna. Sytuacja taka nie miałaby miejsca, gdyby właścicielem określonej ulicy był podmiot prywatny ${ }^{21}$.

Z rozważaniami na temat działań inwazyjnych i nieinwazyjnych łączą się nieuchronnie struktury państwowe. Amerykański autor definiował je jako organizację posiadającą na określonym terytorium monopol na przemoc ${ }^{22}$. Czasami

\footnotetext{
19 Ibidem, s. 317.

20 Ibidem, s. 231-232.

21 Ibidem, s. 232-233.

22 Idem, Etyka wolności, s. 268-269.
} 
Pobrane z czasopisma Annales I - Philosophy and Sociology http://philosophia.annales.umcs.pl Data: 26/04/2023 10:14:19

można spotkać się z definicjami sugerującymi, że państwo to struktura monopolizująca stanowienie prawa. Nie jest to jednak właściwe ujęcie tej kwestii, zwłaszcza w tradycji zachodniej, która operuje pojęciem „państwa prawa” i „rządów prawa" ${ }^{23}$. Można bowiem wyobrazić sobie reżim totalitarny wprowadzający przepisy niemające nic z tą ideą wspólnego. W takiej sytuacji konieczne byłoby wprowadzenie terminu ,państwo bezprawia”, co automatycznie rodzi nieporozumienia odnośnie prawnej definicji struktur państwowych.

Podobnie jak każda instytucja społeczna, państwo ma swój początek w ludzkich działaniach. Forma jego powstania pozostaje ściśle związana z typologią społeczeństw. Pierwotne źródła państwa mogą być dwojakiego rodzaju:

- hegemoniczne, kiedy na danym obszarze pojawia się podmiot narzucający siłą swoją wolę pokojowo współpracującym ludziom,

- kontraktowe, kiedy grupa współpracujących osób dochodzi do wniosku, że konieczne jest zapewnienie im zorganizowanej ochrony przed zagrożeniami wewnętrznymi (na przykład morderstwami i kradzieżą) oraz zagrożeniami zewnętrznymi (najeźdźcami chcącymi ograbić daną grupę lub narzucić jej swoją wolę).

Niewątpliwie głównym motywem kierującym podmiotem chcącym narzucić swoje jarzmo innym zawsze było pasożytnictwo. Jednakże nie można tego rozpatrywać wyłącznie w kategoriach chęci życia na koszt innych. Zazwyczaj dominująca stawała się chęć zaspokojenia swoich wybujałych ambicji, pragnienie panowania i rozkazywania innym. Czynnik ten skutecznie niwelował motywację do osiągania korzyści przez działania kontraktowe. Dla agresora zyskiem samym w sobie było narzucenie własnej woli innym. Doskonale odpowiada to charakterystyce państwa, które nieuchronnie wiąże się z pojęciem władzy i monopolizacji przemocy. Presja wywierana przez agresorów zmuszała tych, którzy jeszcze nie dostali się pod ich panowanie, do zorganizowania struktur obronnych. Stąd też wzięła się druga koncepcja narodzin państwa, opierająca się na dobrowolnym ograniczeniu swojej wolności przez określoną grupę społeczną na rzecz suwerena, który zapewniał im bezpieczeństwo.

Warto odnotować, że Rothbard nie uznawał kontraktowych źródeł państwa. Odrzucał ideę kontraktu społecznego jako konstrukcji zawierającej w sobie przymus stosowany przez większość wobec mniejszości. Zakładając jednak początki państwowości na szczeblu plemiennym, można wyobrazić sobie dobrowolną zgodę wszystkich jego członków na utworzenie tego typu struktur. Nawet odrzucając kontrakt społeczny, nie można wykluczyć kontraktowego sposobu wykształcenia przynajmniej quasi-państwowych struktur.

Istnienie państwa ma zasadnicze znaczenie dla typologii Rothbarda. To właśnie ono jest najwyraźniejszym źródłem działań inwazyjnych, jakie mają miejsce

23 Więcej na temat idei „rządów prawa” zob. F.A. von Hayek, op. cit., s. 168-232. 
w każdym współczesnym społeczeństwie. Każde tego typu struktury wiążą się z elementami przymusu, ponieważ nawet w swojej najbardziej liberalnej formie zakładają przynajmniej monopol na stosowanie przemocy. Żadne społeczeństwo, które wykształciło państwo, nie może zatem zostać uznane za w pełni kontraktowe. Należy równocześnie zaznaczyć, że brak państwa także nie klasyfikuje automatycznie społeczeństwa do kategorii kontraktowego. Aby tak się stało, musiałoby dojść do samorzutnego wykształcenia szeregu prywatnych instytucji społecznych, które wprowadzałyby do anarchii prawdziwy porządek z pominięciem państwa. Problem ten zasadza się na odpowiednim zachowaniu ludzi będących członkami takiego społeczeństwa. Paradoksalny może wydawać się w tym kontekście fakt, że o ile w ocenie amerykańskiego uczonego stan bezpaństwowy jest czymś doskonale przystającym do natury człowieka, to w praktyce zachowania istoty ludzkiej poddają w wątpliwość prawdopodobieństwo wykształcenia społeczeństwa kontraktowego, pozbawionego całkowicie instytucji publicznych w postaci państwa.

Powyższe rozważania dowodzą, że podział Rothbarda, wyróżniający dwa rodzaje społeczeństw, należy postrzegać raczej w kategoriach typów idealnych. W przeciwieństwie do ujęcia idealnotypologicznego Maxa Webera ${ }^{24}$, amerykański autor utrzymywał zawsze, że możliwe jest istnienie i funkcjonowanie społeczeństw w tych skrajnych formach. Twierdził, że w odpowiednich warunkach możliwe jest empiryczne urzeczywistnienie omawianych typów idealnych ${ }^{25}$. Co więcej, sam skonstruował system etyczny, na którym mogłoby oprzeć się w pełni kontraktowe społeczeństwo i starał się dowodzić, w jaki sposób mogłyby funkcjonować poszczególne składowe takiego systemu, określanego przez niego mianem anarchokapitalizmu ${ }^{26}$. Nie zmienia to faktu, że w historii świata nigdy takie społeczeństwo nie istniało. Wiele jego elementów pojawiało się jednak w różnych okresach historycznych, stąd można bezpiecznie założyć, że na pewno możliwe jest funkcjonowanie społeczeństw zbliżonych w jakimś stopniu do tego typu idealnego. Oznacza to w praktyce, że należy utworzyć oś, na której końcach znajdą się omawiane typy idealne. Nie można tej typologii traktować jako dwie całkowicie rozłączne, krystalicznie czyste kategorie, do których da się przypisać każde istniejące współcześnie i historycznie społeczeństwo.

24 Więcej na temat typów idealnych Maxa Webera zob. J. Szacki, Historia myśli socjologicznej. Wydanie nowe, Warszawa 2005, s. 465-466.

25 Trzeba podkreślić, że sam Rothbard nigdy nie traktował społeczeństwa kontraktowego i hegemonicznego jako typy idealne. W ogóle do tego pojęcia się nie odwoływał, jednakże realne spojrzenie na kwestię tej typologii każe jej nadać taki właśnie charakter.

${ }^{26}$ Szczegółowy opis teoretyczny systemu anarchokapitalistycznego, obejmujący również funkcjonowanie prywatnego wymiaru sprawiedliwości, można znaleźć w: M.N. Rothbard, O nowa wolność. Manifest libertariański, Warszawa 2006. 
Pobrane z czasopisma Annales I - Philosophy and Sociology http://philosophia.annales.umcs.pl Data: 26/04/2023 10:14:19

Dwubiegunowa typologia społeczeństw Murraya Rothbarda

129

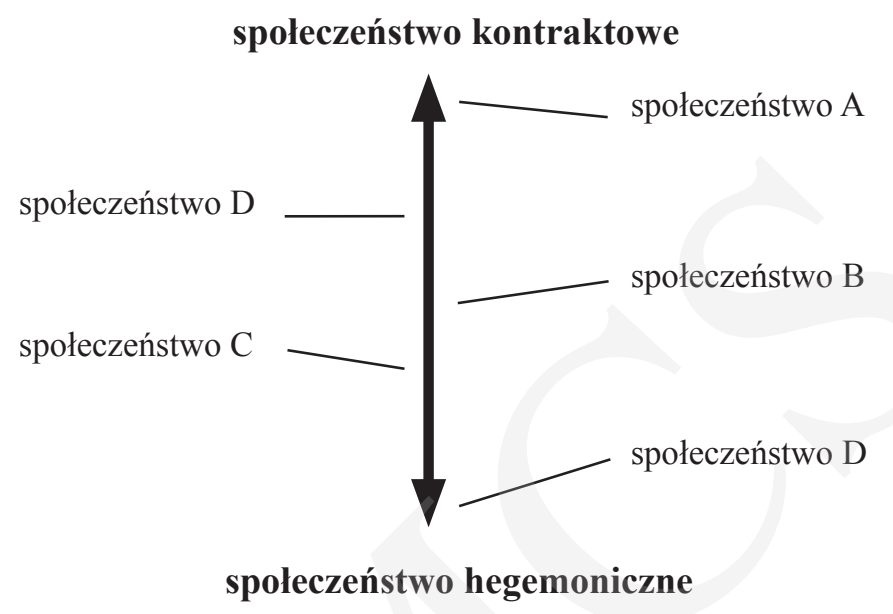

Wykres 1. Dwubiegunowy podział społeczeństw na podstawie typologii Murraya Rothbarda Źródło: opracowanie własne.

Stosując filtr w postaci współczesnego nam świata, można wyróżnić opozycję anarchokapitalizmu i państwa totalitarnego, które w historii najpełniej zostało zrealizowane w Kambodży podczas rządów Czerwonych Khmerów. Model społeczeństwa zbliżony do idealnie hegemonicznego wykształcił się także w nazistowskich Niemczech i ZSRR. Tym, co odróżniało te dwa ostatnie systemy od tego pierwszego, jest zakres sterowania codziennym życiem ludzi. Nawet narodowi socjaliści i bolszewicy nie próbowali stosować takiego zakresu kontroli społecznej, jak Czerwoni Khmerzy. Wystarczy nadmienić, że w III Rzeszy i ZSRR funkcjonowało pojęcie własności prywatnej ${ }^{27}$, podczas gdy w Kambodży całkowicie ją zniesiono.

Problem społeczeństwa kontraktowego jest znacznie bardziej skomplikowany. Nie da się zaprzeczyć, że w historii świata częstszym zjawiskiem były modele społeczeństw zbliżone do hegemonicznych. Te opierające się na relacjach kontraktowych można odnaleźć wśród niektórych grup w okresie przedpaństwowym. Do tego typu idealnego zbliżyło się również społeczeństwo kolonistów angielskich na terenie Ameryki Północnej w XVII i XVIII w. Wiele elementów kontraktowych posiadały także Stany Zjednoczone w początkowym okresie swojego

27 W ZSRR każdy mógł dysponować pewnym majątkiem, jeśli niebędącym formalnie jego własnością, to przynajmniej wykazującym takie cechy. W nazistowskich Niemczech własność prywatna istniała w pełni otwarcie, choć naturalnie z pewnymi zasadniczymi zastrzeżeniami. Dodatkowo należy wskazać, że w porównaniu do Kambodży za rządów Czerwonych Khmerów ludność tych krajów posiadała jednak pewną swobodę decydowania o swoim życiu (np. odnośnie dziedziny kształcenia, a co za tym idzie - docelowego miejsca pracy). Reżim azjatycki zaś starał się sterować wszystkimi kwestiami niemalże na poziomie jednostkowym. 
istnienia (od końca XVII do początku XX w.). Te przykłady można uzupełnić również innymi. W celu uniknięcia nieporozumień przy tworzeniu takiego rankingu, w odniesieniu do typów bardziej empirycznych niż te zaproponowane przez Rothbarda, niezbędne jest wyodrębnienie precyzyjniejszych kryteriów, które mogłyby posłużyć do systematyzowania społeczeństw według tej skali.

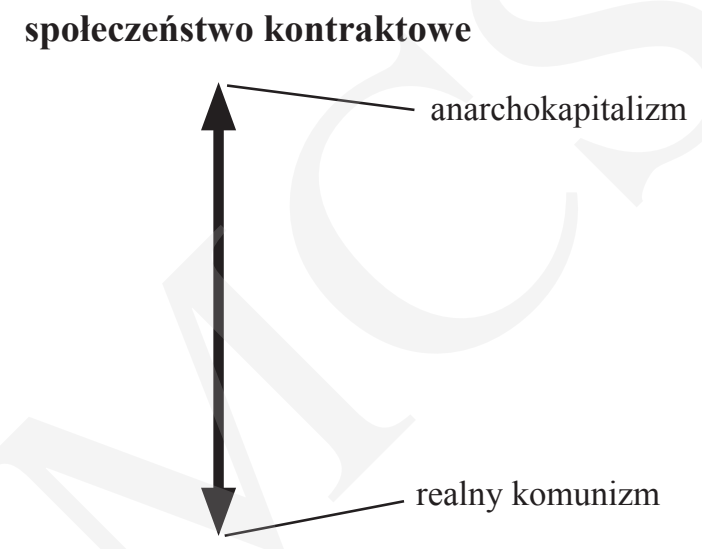

\section{społeczeństwo hegemoniczne}

Wykres 2. Podział społeczeństw na podstawie typologii Rothbarda a ideologie Źródło: opracowanie własne.

Istnieją dwie zasadnicze płaszczyzny, na których realizuje się wolność człowieka: sfera wolności społecznej i sfera wolności gospodarczej. Te dwie kategorie stanowią podstawę, według której należy rozpatrywać społeczeństwa, wykorzystując podział Murraya Rothbarda. Oba obszary pozostają ze sobą w ścisłym związku i w niektórych elementach pokrywają się ze sobą. Może zatem wydawać się pozbawione sensu ich wyróżnianie. Wszak gospodarka zawsze jest częścią społeczeństwa. Za przyjęciem takiego podziału przemawia jednak chaos pojęciowy, do którego przyczyniły się doktryny socjalistyczne. Logiczną implikacją ich postulatu jest likwidacja wolności gospodarczej w celu osiągnięcia wolności społecznej. To błędne pomylenie pojęć wolności i władzy ma swoje źródło w antagonizmie pomiędzy wolnością pozytywną a negatywną. Aksjomat o nieagresji precyzuje, co należy rozumieć pod pojęciem „wolności”. Model kontraktowego społeczeństwa zakłada brak przemocy ze strony innych pod warunkiem, że dana osoba jako pierwsza nie użyła przemocy. Jest to nic innego niż jedna z form definicji wolności negatywnej (tzw. wolności od; na przykład wolności od przemocy, od ucisku, od przymusu) i to właśnie ona musi być rdzeniem szczegółowych cech wolności społecznej i gospodarczej.

Próby wprowadzania do omawianego podziału na szeroką skalę wolności pozytywnej są skazane na niepowodzenie. Jest ona przynajmniej częściowo nie- 
kompatybilna z podziałem Rothbarda ${ }^{28}$. Ma to oczywiście swoje konsekwencje. O wiele łatwiejsze pozostaje odszukanie czynników będących wyznacznikami wolności gospodarczej. To ekonomia, zwłaszcza wolnorynkowa, częściej bazuje na wolności w rozumieniu negatywnym niż pozostałe nauki społeczne czy humanistyczne. Zakłada bowiem istnienie pewnego systemu mogącego funkcjonować niezależnie od struktur państwowych. Działania ingerujące w ten porządek niosą ze sobą zawsze pewne konsekwencje, których charakter i ocena zależą od danej szkoły ekonomicznej. Pozostałe nauki społeczne, na czele z socjologią, znacznie częściej skupiały się na poprawie warunków życia człowieka, przez co bardziej dominujący charakter miała w nich wolność pozytywna. Pozostaje kwestią dyskusyjną, czy przyjęcie jej za podstawę rozumowania w istocie nie prowadziło do degradacji wolności jako takiej (na przykład na skutek wprowadzenia reżimów totalitarnych), a przez to do realnego pogorszenia warunków życia, jednak nie to jest przedmiotem tego tekstu.

W typologię Rothbarda idealnie wpisują się kryteria wolności gospodarczej opracowane wspólnie przez think tanki ze Stanów Zjednoczonych (Cato Institute) i Kanady (Fraser Institute). Prowadzą one coroczny ranking krajów pod kątem swobody gospodarczej, stosując szereg czynników odnoszących się do sfery własności prywatnej, w tym samoposiadania. Przez pracowników instytutu wyróżnione zostały następujące obszary będące składowymi wolności gospodarczej:

a) rozmiar rządu: wydatki, płatności transferowe i subwencje, państwowe przedsiębiorstwa i inwestycje, górna stopa podatkowa (obliczana na podstawie średniej wynikającej z górnej stopy podatku dochodowego i progu wynagrodzenia, od którego ona obowiązuje),

b) system prawny i prawa własności: niezawisłość sędziowska, bezstronność sądów, ochrona praw własności, ingerencja wojska w politykę i rządy prawa, integralność systemu prawnego, prawne egzekwowanie kontraktów, prawne obostrzenia sprzedaży nieruchomości, niezawodność policji, gospodarcze koszty działalności przestępczej,

c) solidny pieniądz: przyrost pieniądza, odchylenie standardowe inflacji, inflacja w ostatnim roku, wolność posiadania kont bankowych w obcych walutach,

d) wolność handlu międzynarodowego: cła, prawne bariery handlowe, kursy walut na czarnym rynku, kontrola przepływu ludzi i kapitału,

28 Należy zaznaczyć, że wykorzystanie wolności pozytywnej w pewnym ograniczonym zakresie jest jednak wskazane. Będzie to zauważalne w dalszej części tekstu przy próbie określenia konkretnych wyznaczników wolności. Ten paradoks wynika z tego, że w istocie wolność pozytywna jest podrzędna względem negatywnej, to znaczy pierwsza zawiera w sobie szereg elementów drugiej, ale tylko w stopniu, w którym nie wchodzą one w otwarty konflikt między sobą. 
e) regulacje gospodarcze: regulacje rynku kredytowego (w tym sektora bankowego), regulacje rynku pracy, regulacje działania przedsiębiorstw ${ }^{29}$.

Niewątpliwą zaletą powyższych kryteriów jest ich kompatybilność z potencjalnym porządkiem anarchokapitalistycznym. Istnienie struktur państwowych lub ich brak nie komplikuje możliwości wykorzystania tych cech do określenia poziomu wolności gospodarczej na danym terytorium. System anarchokapitalistyczny, w rozumieniu Rothbarda, zakłada bowiem istnienie sądów i policji, ale w formie prywatnych instytucji świadczących określone usługi. Oczywiste powinno być także, że brak rządowych instytucji publicznych na hipotetycznym obszarze anarchokapitalistycznym oznacza przyznanie maksymalnej noty na przykład za podpunkt „rozmiar rządu”. W odniesieniu do współczesnych społeczeństw to właśnie państwo (z drobnymi wyjątkami), jako główne źródło działań inwazyjnych, jest pryzmatem tego zagadnienia, a co za tym idzie - musi być dominującym przedmiotem podlegającym ocenie.

Zostało już nadmienione, że większy problem stanowi zagadnienie wolności społecznej. Przy definiowaniu jej kryteriów nie do uniknięcia są pewne odwołania do wolności pozytywnej. Jej rozrostowi zapobiega jednak wolność w rozumieniu negatywnym. Utrzymanie odpowiednich priorytetów pozwala zatem na wykorzystanie niektórych elementów wchodzących powszechnie w skład „wolności do”.

Zadowalającą podstawą do wyodrębnienia kryteriów wolności społecznej jest ranking prowadzony przez amerykańską organizację Freedom House. Co prawda, z racji swoich korzeni ideologicznych pretenduje on do corocznego określania ogólnego poziomu wolności w poszczególnych krajach z niewystarczającym uwypukleniem problemu wolności gospodarczej, jednakże jego użyteczność do identyfikacji wolności stricte społecznej jest dosyć duża. Wyróżnia następujące kategorie:

a) prawa polityczne: proces wyborczy, pluralizm i partycypacja, działanie rządu,

b) swobody obywatelskie: wolność słowa i wyznania, prawo dobrowolnego zrzeszania, rządy prawa, swobody osobiste i prawa jednostek ${ }^{30}$.

Łatwo zauważyć, że w kategorii wolności społecznej znaczenia nabierają kwestie ustrojowe. Jednak problem ten nie jest tak prosty, jak by mógł się wydawać. Można bowiem bez trudu wyobrazić sobie kraj zarządzany w sposób dyktatorski, a jednocześnie charakteryzujący się dużą wolnością gospodarczą (na przykład Chile w okresie rządów Augusto Pinocheta), demokrację, w której pojawiają

${ }^{29}$ Szczegółowy opis każdej kategorii zob. J. Gwartney, R. Lawson, J. Hall, Economic Freedom of the World: 2014 Annual Report, Vancouver 2014, s. 2-7. Wersja elektroniczna dostępna jest pod następującym adresem internetowym: www.cato.org/economic-freedom-world [dostęp: 12.07.2015].

${ }^{30}$ Freedom in the World 2014 Methodology, https://freedomhouse.org/report/freedomworld-2014/methodology\#.VkfqOnvDBkg [dostęp: 12.07.2015]. 
się silne tendencje socjalistyczne (do pewnego stopnia państwa skandynawskie czy niektóre państwa Ameryki Południowej), jak również obszary, na których panuje duża wolność gospodarcza i względna wolność społeczna pomimo braku demokracji (Hongkong). Błędem zatem jest przyjęcie założenia, jakoby demokracja była jedynym i wystarczającym warunkiem najogólniej pojmowanej wolności (czyli wolności negatywnej). W pewnych szczególnych okolicznościach może stać się wręcz dla niej zagrożeniem, jak to niejednokrotnie w historii świata się zdarzało $^{31}$. Warto także przywołać przykład samych Stanów Zjednoczonych i ich ojców założycieli, którzy nie mieli zbyt wysokiego mniemania o nieograniczonej demokracji. Dlatego też ustrój tego kraju został zaplanowany jako republika nie z powszechnym prawem głosu, ale z prawem dla osób, które spełniają odpowiednie standardy oraz istotnymi ograniczeniami konstytucyjnymi dla władz. Wraz $\mathrm{z}$ upływem lat następowały przekształcenia w tej materii, by ostatecznie osiągnąć ustrój demokratyczny zbliżony w swojej formie do tego, czego chcieli uniknąć ojcowie założyciele. Należy zatem wyraźnie zaznaczyć, że powszechne, pozytywne uprawnienie do udziału w wyborach nie oznacza bynajmniej automatycznego osiągnięcia stanu wolności społecznej (a tym bardziej ogólniejszej wolności negatywnej), choć może być czynnikiem, który się do tego przyczyni.

Oczywiście powyższy problem zmusza do postawienia pytania, czy w takim przypadku jest sens uwzględniania kwestii ustrojowych w typologii Rothbarda, zwłaszcza że jednym z jego typów idealnych jest społeczeństwo nieposiadające struktur państwowych $\mathrm{w}$ ich powszechnym rozumieniu. Trzeba jednak zauważyć, że większość pozostałych kryteriów wolności według Freedom House była w najpełniejszym wymiarze realizowana przede wszystkim w krajach posiadających systemy demokratyczne lub ustrój do nich podobny (na przykład republikę). Już to jest wystarczającym powodem uwzględnienia go w tych rozważaniach. Ustrój stanowi bowiem czynnik sprzyjający lub utrudniający rozwój innych aspektów wolności.

Trudna może być w tym kontekście kwestia samego anarchokapitalizmu, a konkretnie zagadnienie, jak odnieść do takiej hipotetycznej konstrukcji kwestie ustrojowe. Jednym z możliwych rozwiązań jest założenie, że w istocie nieskrępowane żadnymi państwowymi regulacjami społeczeństwo ${ }^{32}$ jest pełnym uosobieniem także swobody politycznej, co skutkowałoby przyznaniem maksymalnej noty za poświęconą temu część klasyfikacji.

Nie jest to jednak jedyny problem klasyfikacji amerykańskiego think tanku. Przykładowo prawo do dobrowolnych zrzeszeń, jako jeden z podpunktów, zakła-

31 Najbardziej rażącym przykładem demokratycznego zamachu na wolność jest powstanie III Rzeszy, ale podobne procesy były także udziałem niektórych krajów Ameryki Południowej.

32 Trzeba zaznaczyć, że w potencjalnym społeczeństwie kontraktowym, czyli anarchokapitalistycznym, istniałyby - według amerykańskiego autora - regulacje jako takie, ale byłyby one efektem samorzutnych sił społecznych i rynkowych, a nie inwazyjnych działań rządzących. 
da uprawnienia związków zawodowych. Założenie jest więc takie, że im więcej praw posiadają związki zawodowe, tym wyższy poziom prawa do dobrowolnych zrzeszeń i tym wyższy poziom wolności społecznej. Jest to błąd wynikający z marksistowskich korzeni ideologicznych, prowadzący do błędnego rozumienia wolności, konkretnie zaś z przyznania prymatu wolności pozytywnej, która w takim przypadku przekształca się we władzę. Owszem, wolność do zrzeszania się $\mathrm{w}$ związki zawodowe jest jednym $\mathrm{z}$ aspektów wolności stowarzyszeń, ale nadawanie związkom specjalnych uprawnień w stosunku do wszelkich innych pozarządowych organizacji to coś całkowicie przeciwnego. Kompatybilność kryteriów Freedom House z dwubiegunowym podziałem Murraya Rothbarda jest zatem uzależniona od dokonania stosownych modyfikacji.

Warto zauważyć, że niektóre aspekty pokrywają się z tymi, które określają wolność gospodarczą. Wynika to z prostego faktu, że bez pewnych elementów niemożliwe jest funkcjonowanie obu sfer wolności. Tak jest w przypadku rządów prawa. Dyskusji może podlegać jedynie rozłożenie ciężarów na poszczególne składowe rządów prawa w wolności gospodarczej i wolności społecznej. Z kolei część odnosząca się do swobód obywatelskich i praw jednostek pozostaje silnie związana z pewnymi aspektami wolności gospodarczej. Opracowanie w pełni spójnych kryteriów przystających do podziału Rothbarda to jednak zadanie na znacznie obszerniejszą pracę.

Ostateczna pozycja danego społeczeństwa (nierzadko współcześnie utożsamianego z państwem) na zaproponowanej skali powinna być określona na podstawie średniej punktacji z kategorii wolności gospodarczej i kategorii wolności społecznej. Oczywiście przed realizacją takiego zadania trzeba podjąc się stosownej modyfikacji not, wykorzystywanych przez think tanki w prowadzonych przez nie rankingach, w celu uzyskania zadowalającej spójności. Kwestią otwartą pozostaje także modyfikacja samych kryteriów. Wydaje się natomiast pewne, że obie kategorie wolności powinny mieć równą wagę przy rozpatrywaniu pozycji określonego społeczeństwa na osi.

Użyteczność podziału Murraya Rothbarda i zaproponowane powyżej kryteria typologizacji nie ograniczają się bynajmniej do współczesnych społeczeństw. Za ich pomocą można analizować także historyczne społeczeństwa (czyli historyczne państwa), o ile tylko dostępne są wystarczające materiały źródłowe. Pozwoliłoby to na przejrzystą identyfikację okresów historycznych, w których ludzkość cieszyła się największą realną wolnością. Dane takie dostarczyłyby również informacji o tym, jak przedstawia się korelacja pomiędzy wolnością i dynamiką rozwoju gospodarczego i społecznego. Nie ma też żadnych przeszkód, by według tej skali szeregować ideologie czy programy polityczne poszczególnych partii. Oferuje on znacznie większą przejrzystość niż bardziej specjalistyczne kategoryzacje. Może stać się zatem ciekawą i dosyć obiektywną alternatywą dla podziału lewica - prawica. 
Na powyższych przykładach zapewne nie kończy się lista możliwych zastosowań omawianego podziału. Pewnym ograniczeniem może być w tej materii fakt, że opiera się on na pojęciu wolności. Dlatego też zadania, które są przed nim stawiane, muszą to uwzględniać. Nie jest jednak trudno dostrzec, że w typologii Rothbarda kryje się duży potencjał naukowy.

\section{BIBLIOGRAFIA}

Chafee Z., Freedom of Speech in War Time, "Harvard Law Review" 1919, No. 32.

Freedom in the World 2014 Methodology, https://freedomhouse.org/report/freedom-world-2014/ methodology\#.VkfqOnvDBkg [dostęp: 12.07.2015].

Gwartney J., Lawson R., Hall J., Economic Freedom of the World: 2014 Annual Report, Vancouver 2014 (www.cato.org/economic-freedom-world, dostęp: 12.07.2015).

Hayek F.A. von, Konstytucja wolności, Warszawa 2011.

Locke J., Esej dotyczący prawdziwych początków, zakresu i celu rządu obywatelskiego, [w:] Dwa traktaty o rządzie, Warszawa 1992.

Mill J.S., On Liberty, London 1921.

Mises L. von, Ludzkie działanie. Traktat o ekonomii, Warszawa 2011.

Nozick R., Anarchia, państwo i utopia, Warszawa 2010.

Rothbard M.N., Ekonomia wolnego rynku, t. 1, Warszawa 2007.

Rothbard M.N., Etyka wolności, Warszawa 2010.

Rothbard M.N., O nowa wolność. Manifest libertariański, Warszawa 2006.

Rothbard M.N., War, Peace, and the State, [w:] Egalitarianism as a Revolt Against Nature and Other Essays, Auburn 2000.

Szacki J., Historia myśli socjologicznej, Warszawa 2005.

Turowski J., Socjologia. Wielkie struktury społeczne, Lublin 2000.

\section{SUMMARY}

The article presents a bipolar typological system developed by the American economist Murray Rothbard. Focusing on describing two ideal types, it tries to introduce criteria in order to sort human communities according to indexing axis defined by contractual society on the one side and by hegemonic society on the other. The basis of the considerations is the Rothbardian notion of "violence" as the coercive type of human actions and the notion of "contract" as the voluntary type of actions. The text raises also the problem of positive and negative liberty as a key element of the typology presented by the American author. Furthermore it proposes possible uses of the discussed rating in social science.

Keywords: Murray Rothbard; contractual society; hegemonic society; violence; contract; human actions; liberty, state 